\title{
Evaluation of the Cariogenic and Erosive Potential of Some Beverages Consumed in Enugu Metropolis, South East Nigeria
}

\author{
C. Uzoamaka Maduakor ${ }^{1 *}$, F. Ngozi Onyemelukwe ${ }^{1}$, N. Innocent Okonkwo ${ }^{1}$, \\ C. Nkiruka Azubuike ${ }^{1}$, O. Cornelius Ogu ${ }^{1}$, I. Paul John Chukwu ${ }^{1}$ \\ and N. Sam Maduakor ${ }^{2}$ \\ ${ }^{1}$ Department of Medical laboratory Sciences, Faculty of Health Science and Technology, \\ College of Medicine, University of Nigeria, Enugu Campus, Nigeria. \\ ${ }^{2}$ Faculty of Dentistry, College of Medicine, University of Nigeria, Enugu, Nigeria.
}

\begin{abstract}
Authors' contributions
This work was carried out in collaboration among all authors. Author CUM conducted the study and drafted the manuscript. Author FNO designed and supervised the study. Author NIO wrote the protocol and assisted in laboratory investigations. Author CNA and managed the analyses of the study. Authors OCO and IPJC managed the literature search and author NSM critically reviewed the manuscript. All authors read and approved the final manuscript.
\end{abstract}

Article Information

DOI: 10.9734/ARRB/2020/v35i230188
Editor(s):
(1) Paola Angelini, University of Perugia, Perugia, Italy.
Reviewers:

(1) Riccardo Beltrami, University of Pavia, Italy.

(2) Bel'skaya Lyudmila, Omsk State Pedagogical University, Russia.

(3) Coldea Teodora Emilia, University of Agricultural Sciences and Veterinary Medicine of Cluj-Napoca, Romania.

Complete Peer review History: http://www.sdiarticle4.com/review-history/55738

Original Research Article

Received 28 January 2020

Accepted 04 April 2020

Published 09 April 2020

\begin{abstract}
Dental caries is a global infectious disease and the most common oral cavity disease. Among the theories which explain caries is the activity of acids produced by bacteria resulting from dietary fermentation of carbohydrates (sugars). Modernization has led to change in our diet and life style and the beverage industries are having a field day. Though people are aware of the harm caused by these beverages and fruit juices on the dental hard tissues, they still choose to guzzle them. The study was an in vitro analysis of cariogenic and erosive potential of different beverages mostly consumed in Enugu metropolis, South Nigeria. Seventeen samples were analyzed physically and chemically using the following parameters, $\mathrm{pH}$, titratable acidity (TA), total soluble solid content
\end{abstract}


(TSSC), reducing sugars (RS), non-reducing sugars (NRS) and total sugars (TS). Standard analytical techniques were used including potentiometry for endogenous $\mathrm{pH}$, Association of Official Analytical Chemists approved method for titratable acidity, Brix refractometry using Abbe refractometer for TSSC and Fehling's method for sugars. Coke pressented the highest pH (2.83) followed by La casara 2.92 and the least was Bobo strawberry 4.6. California and Holladia recorded the least and highest TA values of $0.04 \%$ and $0.26 \%$ respectively. Bobo strawberry had the least TSSC $\left(6.81^{\circ}\right.$ Brix) and the highest was Hollandia yogurt (16.34 Brix). Seven Up presented the highest reducing sugar $20.45 \mathrm{~g} / 100 \mathrm{ml}$. Mirinda and Bobo strawberry had the highest total sugars $68.90 \mathrm{~g} / 100 \mathrm{ml}$ each. For non-reducing sugars, the values ranged from $0 \mathrm{~g} / 100 \mathrm{ml}$ (Chivita apple) to $65.45 \mathrm{~g} / 100 \mathrm{ml}$ (Bobo strawberry). There were significant differences among the samples for reducing sugars $(P<0.05)$. These beverages showed low endogenous $\mathrm{pH}$ that were below the critical value for enamel demineralization $(\mathrm{pH}<5.5)$. They are potentially hazardous to the teeth and should not be consumed regularly because of their low $\mathrm{pH}$ and high sugar content.

Keywords: Dental caries; erosion; pH; sugar; Enugu; Nigeria.

\section{INTRODUCTION}

Dental caries is a global infectious disease and the commonest disease in the oral cavity [1,2]. Amidst the theories that describe genesis of caries is the activity of acids formed by bacteria as a result of fermentation of carbohydrates (sugars) from diet [2]. There is therefore strong relationship between oral health and sugars. Diet has effect on the soundness, the composition, quantity and $\mathrm{pH}$ of the saliva, and the $\mathrm{pH}$ of the plaque. Fermentable carbohydrates including sugars after being hydrolyzed by salivary amylase, furnish substrates for the action of oral microflora, which in turn lowers salivary and plaque $\mathrm{pH}$. The corollary is the genesis of tooth demineralization [1].

Physicians, dentists, and parents are facing a serious challenge because of consumption of junk and unwholesome food and drinks leading to co morbidity, including type 2 diabetes, obesity, caries, and dental erosion [2]. Recently, dental erosion has been reported to be a general serious health challenge $[3,4,5]$ and this may have been due to increase in the consumption of soft drinks, fruit juice and sport drinks [5]. Dental erosion is the chemical dissolution of the surface of the teeth due to acid attack without the participation of microorganism. Development has resulted in rapid change in diet and lifestyles. Refined food with increased access to readymade drink has become the order of the day [6, 7]. Consumption of carbonated drink and fruit juices has been on increase. Majority of the populace see soft drink consumption as safe and harmless, however, there have been a significant health issues linked with frequent consumption of soft drinks [5]. Parents influence, peer pressure, diet fallacies pleasure and tastes have been responsible for the increase in the consumption of these drinks $[5,7]$. Report has shown that there is a correlation between the quantity and regular consumption of sugar and prevalence and seriousness of caries and erosion [2]. All these carbonated drinks have a $\mathrm{pH}$ of 2 to 3 and may cause a pronounced loss of dental hard tissues through erosion and it an increasing challenge to teenagers [2]. Majority of these beverages contain single to double food acidulants namely phosphoric acid and citric acid [5]. Sometimes malic and or tartaric acid may be used. Citric, malic and tartaric acids are erosive because of their inherent tendency to chelate calcium at higher $\mathrm{pH}[5,6]$. The titratable acidity and a low $\mathrm{pH}$ are the main cause of erosive lesions, and all these factors including sugar content contribute to the formation of cavity [8].

It costs a lot of money and time to restore extensive tooth wear [5]. Enamel dissolution has a critical $\mathrm{pH}$ of 5.5 and any food or drink lower than 5.5 may contribute to or stimulate erosion [1]. The commonest cause of dental erosion in young people is the consumption of acidic beverage such as carbonated sport drinks and fruit juice. These have been reported to be associated with loss of dental enamel, particularly when consumed during periods when there is low salivary flow such as immediately after serious sport activities [3,8,9].

According to recent global soft drink market analysis, Nigeria ranked fourth in the world, coming after United States of America, China and Mexico which ranked first, second and third respectively [10]. Attention has been focused on economic values without considering the health implications or impact of the consumption of soda and other sweetened beverages in sub 
Saharan Africa [11]. Recently interest has been kindled to determine some chemical and physical properties of beverages such as endogenous $\mathrm{pH}$, titratable acidity (TA), total soluble solid content (TSSC) or degree Brix $\left({ }^{0} \mathrm{Bx}\right)$, and their impact on dental bio film $[12,13,14]$.

In the view of high consumption of soft drinks and other beverages among Nigerians and lack of federal government concern in streamlining this habitude, the purpose of this study was to analyze in vitro, the erosive and cariogenic potential of some beverages consumed in Enugu metropolis by assessing some of their physical and chemical parameters.

\section{MATERIALS AND METHODS}

\subsection{Study Design}

The evaluation of endogenous $\mathrm{pH}$, titratable acidity, total soluble solids content (TSSC-\% Brix) and sugar levels were done on 17 randomly selected soft drinks and fruit juices commonly consumed in Enugu Metropolis South East Nigeria. Samples were bought from Ogbete main market and Shoprite Enugu. Each analysis was done in triplicate. The carbonated drinks were degassed by pouring them into beakers and placed inside the water bath containing warm water. For several minutes, they were vigorously stirred and allowed to stand 15 minutes and stirred once more. The drinks were brought out and allowed to come back to room temperature.

\section{$2.2 \mathrm{pH}$ Measurement}

The endogenous $\mathrm{pH}$ of each fruit juice and soft drink was evaluated at room temperature $\left(28.0^{\circ} \mathrm{C}\right.$ ) with $\mathrm{pH}$ meter (Hanna Instruments, USA) immersed into each solution. Buffer standards of $\mathrm{pH} 7$ and 4 were used to calibrate the $\mathrm{pH}$. Into a beaker was placed $20 \mathrm{mls}$ of pure beverage/ fruit juice and $\mathrm{pH}$ meter was placed into the sample and the value recorded was [13].

\subsection{Total Soluble Solids Content (TSSC)}

Abbe Refractometer (New Delhi, Delhi) was used to do TSSC analysis. Distilled water was used calibrated the equipment (refractive index 1.3325 and $0^{\circ}$ Brix at $28.0^{\circ} \mathrm{C}$ ) [13] and readings of the samples were taken ( ${ }^{\circ}$ Brix or $\left.\mathrm{g} / 100 \mathrm{ml}\right)$.

\subsection{Titratable Acidity (TA)}

Method adopted by the Association of Official Analytical Chemists (2000) was used to measure the titratable acidity (TA) [15]. The quantity of 0.1 $\mathrm{N} \mathrm{KOH}$ solutions required for the product to attain a neutral $\mathrm{pH}$ or a $\mathrm{pH}$ value above it. $\mathrm{A} 10$ $\mathrm{ml}$ fraction of the diluted sample was titrated ( $10 \%$ solution of the sample) with the $0.1 \mathrm{~N} \mathrm{KOH}$ solution until the substance attained a $\mathrm{pH}$ value between 8.2- 8.4, equivalent to the end point of the phenophthalein. $\mathrm{PH}$ meter (Hanna instruments USA) was used to take the readings [13]. On reaching this value, the volume of $\mathrm{KOH}$ was recorded and the percentage of the acid was calculated using the following equation below, and the result was reported as percentage of citric acid.

$$
=\frac{\mathrm{V} \times \mathrm{Nap} \times \mathrm{F} \times \mathrm{meq}-\mathrm{g}(\text { Citric acid }) \times 100}{\text { Sample }}
$$

Where $\quad \mathrm{V}=\mathrm{KOH} \quad$ Volume, Nap=Normal concentration of the $\mathrm{KOH}$ base; $\mathrm{F}=$ Normal correction factor; meq-g=miliequivalent per gram of citric acid; Sample=volume of the beverage.

\subsection{Reducing Sugars, Non-reducing Sugars and Total Sugars}

The method adopted by the Association of Official Analytical Chemist (2000) was used for reducing sugars, non-reducing sugars and total sugars and the results were expressed in $\mathrm{g} / \mathrm{dl}$ [15].

\subsection{Reducing Sugars}

For the evaluation of reducing sugar, a portion equivalent to $5 \mathrm{~g}$ of sample was measured into a 250 volumetric flask and $10 \mathrm{ml}(20 \%)$ neutral lead acetate solution was added to it, the solution was diluted to mark with distilled water and filtered. An aliquot of $25 \mathrm{ml}$ of clarified filtrate was transferred into $500 \mathrm{ml}$ volumetric flask containing $100 \mathrm{ml}$ of distilled water. Potassium oxalate $(10 \%)$ was then added in small amount until there is no further precipitation. The solution was made to mark and filtered through a Whatman No 1 filter paper. The filtrate was transferred to a $50 \mathrm{ml}$ burette.

\subsection{Titration}

Into $250 \mathrm{ml}$ conical flask $5 \mathrm{mls}$ of Fehling's A and $B$ were pipette and mixed, then $10 \mathrm{mls}$ of distilled water and few glass beads were added and 
Table 1. Brand name, ingredients and manufacturers of the tested beverages

\begin{tabular}{|c|c|c|c|}
\hline$\underline{\mathbf{S} / \mathbf{N}}$ & Commercial brand/name & Active principal ingredients & Manufacturer \\
\hline 1 & Sprite & $\begin{array}{l}\text { Carbonated water, sugar, citric acid, lime } \\
\text { and lemon flavours sodium citrate sodium } \\
\text { Benzoate }\end{array}$ & Coca cola \\
\hline 2 & Fanta & $\begin{array}{l}\text { Carbonated water, sugar, citric acid, } \\
\text { Ascorbic acid, stabilizers (E414, E415), } \\
\text { orange flavor, sodium benzoate, } \\
\text { colourants, sunset yellow and flavor } \\
\text { Tartrazine. }\end{array}$ & Coca-cola \\
\hline 3 & Coke & $\begin{array}{l}\text { Carbonated water, sugar, caramel colour, } \\
\text { phosphoric acid, cola flavor, caffeine }\end{array}$ & Coca-cola \\
\hline 4 & 5 Alive Apply fruit Nectar & $\begin{array}{l}\text { Water, concentrated apple juice } 25 \% \\
\text { minimum sugar, pectins, citric acid, Apple } \\
\text { flavor caramel colour, Vit. C and E }\end{array}$ & Coca-cola \\
\hline 5 & 7up & $\begin{array}{l}\text { Sweetened carbonated beverage: } \\
\text { carbonated water, sugar, citric acid malic } \\
\text { acid, sodium citrate lemon and lime } \\
\text { flavours }\end{array}$ & $\begin{array}{l}\text { Seven up bottling } \\
\text { company }\end{array}$ \\
\hline 6 & Pepsi & $\begin{array}{l}\text { Carbonated water sugar, caramel, } \\
\text { phosphoric acid, caffeine, Gum Arabic, } \\
\text { cola flavor }\end{array}$ & $\begin{array}{l}\text { Seven up bottling } \\
\text { company }\end{array}$ \\
\hline 7 & Mirinda orange & $\begin{array}{l}\text { Sweetened carbonated beverage: sugar, } \\
\text { citric acid Arabic gum, sodium benzoate; } \\
\text { Ester gum, orange flavor, sunset yellow, } \\
\text { Tartrazine }\end{array}$ & $\begin{array}{l}\text { Seven up bottling } \\
\text { company }\end{array}$ \\
\hline 8 & La casera (Apple drink) & $\begin{array}{l}\text { Carbonated water, Apple juice } 4 \% \text {, sugar, } \\
\text { Apple flavor, Acidulants: Malic acid and } \\
\text { citric acid preservative: sodium benzoate, } \\
\text { colour: caramel }\end{array}$ & $\begin{array}{l}\text { Classic beverage } \\
\text { Nigeria Ltd (CB) }\end{array}$ \\
\hline 9 & Ribena (Blackcurrant) & $\begin{array}{l}\text { Water, sugar, black currant juice } \\
\text { concentrate, Glucose syrup, citric acid, } \\
\text { vitamin C, Preservative: (Potassium } \\
\text { sobate), Grape colour (E163) }\end{array}$ & GlaxoSmithKline \\
\hline 10 & $\begin{array}{l}\text { California sun (straw berry } \\
\text { drink juice) }\end{array}$ & $\begin{array}{l}\text { Water, sugar, Xanthan Gum, Strawberry, } \\
\text { concentrate, sodium benzoate potassium } \\
\text { sorbate, Pectin, Ascorbic acid (35mg/100l) } \\
\text { Citric acid, strawberry flavours, Red } \\
\text { carmozine, Aspartame, Acesulfame-k }\end{array}$ & $\begin{array}{l}\text { Frutta Juice and } \\
\text { SERVICES Nig Ltd }\end{array}$ \\
\hline 11 & $\begin{array}{l}\text { Bobo (Straw berry milk } \\
\text { drink) }\end{array}$ & $\begin{array}{l}\text { Water, full cream milk, sugar, strawberry } \\
\text { juice, citric acid, carboxy methyl cellulose, } \\
\text { sodium citrate, strawberry flavor, milk } \\
\text { flavor, ponceau } 4 \text { R, Potassium sorbate, } \\
\text { Acesulfame-k, sucrose, fatty acid esters, } \\
\text { vitamin C }\end{array}$ & $\begin{array}{l}\text { Bobo food and } \\
\text { beverage limited }\end{array}$ \\
\hline 12 & Bobo (orange milk drink) & $\begin{array}{l}\text { Water, full cream milk, sugar, orange } \\
\text { juice, citric acid, carboxymethyl cellulose, } \\
\text { sodium citrate, orange flavor, milk flavou, } \\
\text { Poceau 4R, Yellow tartrazine, potassium } \\
\text { sorbate, Acesulfame-k, Vitamin C }\end{array}$ & $\begin{array}{l}\text { Bobo food and } \\
\text { beverage limited }\end{array}$ \\
\hline 13 & Twist (Apple fruit milk drink) & $\begin{array}{l}\text { Milk powder, apple fruit juice, butter oil, } \\
\text { sugar, stabilizers, water, vitamins }\end{array}$ & Condia Nutrition \\
\hline
\end{tabular}




\begin{tabular}{|c|c|c|c|}
\hline$\overline{14}$ & Capri-sonne orange drink & $\begin{array}{l}\text { Water, sugar, orange juice concentrate, } \\
\text { natural fruit drink, no artificial flavours, } \\
\text { colours, sweeteners or preservatives } \\
\text { added }\end{array}$ & $\mathrm{CH} 1$ limited \\
\hline 15 & Chivita (Apple juice) & $\begin{array}{l}100 \% \text { fruit juice, } 0 \% \text { added sugar, no } \\
\text { preservative No artificial colours, no } \\
\text { artificial flavor }\end{array}$ & $\mathrm{CHI}$ Limited \\
\hline 16 & Chivita (Orange) & $\begin{array}{l}10 \% \text { fruit juice, } 0 \% \text { added sugar, no } \\
\text { preservative No artificial colours, no } \\
\text { artificial flavor }\end{array}$ & $\mathrm{CHI}$ Limited \\
\hline 17 & Hollandia yoghurt & Yoghurt base, sugar, stabilizer, water & CHI Limited \\
\hline
\end{tabular}

heated to boiling. Three drops of $1 \%$ methylene blue were added and the mixture was titrated with the already made sample solution until the reducing sugar present in the sample was completely reduced by the Fehling's solution showing blue to brick-red colour.

The percentage of reducing sugars was calculated using the following equation.

Reducing sugars \%

$=\frac{\text { Dilutions } \times \text { Factor of Fehling }(\mathrm{gm}) \times 100}{\text { Weight of sample } \times \text { Titre }}$

\subsection{Total Sugars}

Method used by Calvalcanti as per protocol where $5 \mathrm{ml}$ of concentrated hydrochloric acid was added to $25 \mathrm{ml}$ of each beverage and put in double boiler for 10 minutes. The mixture was cooled and $5 \mathrm{ml}$ diluted saturated lead acetate and distilled water was added. Ten milliliter of mixture of Fehlings was added followed by $40 \mathrm{ml}$ of distilled water. These were heated to boiling for $4 \mathrm{~min}$. Titration was done with $25 \mathrm{ml}$ of diluted filtrate against the Fehlings solution in the presence of methylene blue until brick red precipitate was obtained [13]. The spent volume was recorded and the total sugar content was calculated using the equation below;

Total sugar content $(\%)=F E Q \times$ dilution $\times$ 100/VTITRATION

Where FEQ=Equivalence Factor; VTITRATION= volume spent

\subsection{Non-reducing Sugars}

Subtracting the reducing sugars from the total sugars and multiplying the value by the conversion factor of glucose in sucrose which is 0.95 gives the estimated value of non-reducing sugar. Grams of sucrose per dl of sample were used to express the result.

\subsection{Determination of Fehling Factor}

Into $500 \mathrm{ml}$ volume flask containing $50 \mathrm{mls}$ of distilled water, $4.75 \mathrm{~g}$ of analar grade sucrose was added followed by $5 \mathrm{mls}$ of conc. HCL $(1+1)$. This was boiled in a water bath at $70^{\circ} \mathrm{C}$ for 1hour cooled and neutralized with $\mathrm{NaOH}$ solution and then made up to volume, mixed and then 50 mls was transferred to $100 \mathrm{ml}$ flask and finally made up to volume. It was then transferred to a burette and titrated using $5 \mathrm{mls}$ each of Fehling solution.

Fehling factor $=\frac{\text { Titre } \times \text { weight of sucrose in } g}{500}$

\subsection{Statistical Analysis}

Data generated were analyzed with GraphPad Prism version 5.0. The student's t-test was used to calculate differences between means while analysis of variance (ANOVA) was used to estimate difference between group mean. Categorical variables were presented as frequencies (percentages) while continuous variables were presented as mean \pm standard deviation. $P<0.05$ was considered statistically significant.

\section{RESULTS}

The results of the physical and chemical parameters differed among the evaluated beverages. Table 2 shows the distribution of $\mathrm{pH}$ and TA mean values for the tested beverages. All the beverages tested showed $\mathrm{pH}$ below the critical value of 5.5 . The $\mathrm{pH}$ values ranged from 2.83+0.01 (Coke) to 4.56+0.01 (Bobo straw berry). The least TA value was recorded for California sun $0.04 \pm 0.002$ while the highest was Hollandia yoghurt $0.26 \pm 0.001$.

Table 3 shows the distribution of TSSC, reducing sugars, non-reducing sugars and, total sugars of the tested samples. The least TSSC was shown by Bobo straw berry $6.81 \pm 0.01$ while the highest TSSC was presented by Hollandia yoghurt $(16.32) \pm 0.01$.

The highest reducing sugars value reported for 7 up (20.45+ and the least was caprisonne-orange 
2.76 +0.01 . Bobo straw berry milk drink and chivita (apple juice) had no reducing sugar.

Non-reducing sugars values ranged from $1.42 \pm 0.01$ for california sun to $64.77 \pm 0.02$ for Hollandia yoghurt.

\section{DISCUSSION}

Beverage consumption has been on increase and this is dangerous to oral health. Strong relationship exists between sugars and oral health. In addition to sugar, other factors that influence the cariogenic potential of drinks or food include frequency of intake, consistency and form, time span of exposure, composition of food, eating order, flow of saliva, buffer presence, and oral hygiene [1]. Regular intake of sugary drinks has become a major cause of caries and dental erosions. They are known to cause harm to the teeth because of two properties namely the low $\mathrm{pH}$ and titratable acidity of the drinks which can cause erosion on the dental hard tissues and secondly, the fermentable sugars in the drinks which are acted upon by plague micro-organisms to produce acid in the dental plaque, resulting in demineralization thereby leading to caries [16]. Sugars that we consume may occur naturally or may be added [1]. The contents of these drinks include aspartame, phosphoric acid, maleic acid, citric acid, phosphates, sugar, caffeine, water and fluoride depending on the type. Some of these beverage are classified as carbonated drinks, energy drinks or fruits juices.

The practical method to assess erosive potential of beverages is to evaluate its $\mathrm{pH}$.

Our study showed that all the seventeen tested beverages had $\mathrm{pH}$ lower than 5.5 which is the critical value for dental demineralization.

The $\mathrm{pH}$ ranged from 2.83 for coke to 4.56 for Bobo strawberry. Some researchers reported a range of 3.32-4.44 [8]. The TA which is the amount of base required to bring a solution to neutral $\mathrm{pH}$ were low in our work. It ranged from 0.04-0.26. The type of acid contained in the beverage also enhances the demineralization power of the drink; citric acid has a greater erosive potential than maleic, phosphoric acid and hydrochloric acid $[5,17,18]$. The high erosive potential of the citric acid is associated with its power to form complexes with the calcium ions present in the hyroxiapatite [19]. Beverages with citric acid are known to be potentially erosive [20]. The risk of erosion has a strong relationship to the quantity and frequency of consumption. Whenever there is an erosive challenge, behavioral factors act to play a role in modifying the level of erosive tooth wear. The method of taking in these beverages (gulping, sipping, use of a straw) affects the duration of contact between the teeth and challenge, consequently the rate and length of exposure to an erosive

Table 2. Distribution of the beverages based on their mean values and standard deviation for endogenous $\mathrm{pH}$ and titratable acidity

\begin{tabular}{|c|c|c|c|c|c|}
\hline \multirow{2}{*}{ Coca-cola } & \multirow{2}{*}{$\begin{array}{l}\text { Name of beverage } \\
\text { Sprite }\end{array}$} & \multicolumn{2}{|c|}{$\begin{array}{l}\text { Endogenous pH } \\
\text { Mean } \pm \text { SD }\end{array}$} & \multicolumn{2}{|c|}{$\begin{array}{l}\text { Titratable acidity } \\
\text { Mean } \pm \text { SD }\end{array}$} \\
\hline & & 3.75 & 0.01 & 0.07 & 0.001 \\
\hline & Fanta & 3.27 & 0.01 & 0.11 & 0.001 \\
\hline & Coke & 2.83 & 0.01 & 0.08 & 0.001 \\
\hline & 5 Alive & 3.17 & 0.01 & 0.18 & 0.001 \\
\hline \multirow{3}{*}{ 7-up bottling company } & 7 up & 3.71 & 0.01 & 0.12 & 0.001 \\
\hline & Pepsi & 2.84 & 0.01 & 0.05 & 0.002 \\
\hline & Mirinda & 3.17 & 0.01 & 0.08 & 0.002 \\
\hline Classic beverage limited & La casara apple drink & 2.92 & 0.01 & 0.12 & 0.090 \\
\hline GlaxoSmithKline & Ribena & 3.28 & 0.01 & 0.08 & 0.001 \\
\hline $\begin{array}{l}\text { Frutta Juice and services } \\
\text { Nig Ltd }\end{array}$ & California sun & 3.75 & 0.01 & 0.04 & 0.002 \\
\hline Bobo food and beverage & Bobo strawberry milk drink & 4.56 & 0.01 & 0.16 & 0.001 \\
\hline limited & Bobo Orange & 4.48 & 0.01 & 0.15 & 0.002 \\
\hline Condia nutrition & Twist apple fruit milk drink & 4.26 & 0.02 & 0.13 & 0.002 \\
\hline \multirow{4}{*}{ Chi- Limited } & Capri-sonne orange drink & 4.00 & 0.01 & 0.08 & 0.001 \\
\hline & Chivita (apple juice) & 4.04 & 0.02 & 0.09 & 0.06 \\
\hline & Chivita (orange) & 4.41 & 0.01 & 0.20 & 0.001 \\
\hline & Hollandia yoghurt & 4.30 & 0.01 & 0.26 & 0.001 \\
\hline
\end{tabular}


Table 3. Reducing Sugars (RS), Non-reducing Sugars (NRS), Total Sugars (TS) and Total Soluble Solute Content (TSSC) all in g/dl of various beverages

\begin{tabular}{|c|c|c|c|c|c|c|c|c|}
\hline \multirow{2}{*}{$\begin{array}{l}\text { Company name } \\
\text { Coca-cola }\end{array}$} & \multirow{2}{*}{$\begin{array}{l}\text { Name of beverage } \\
\text { Sprite }\end{array}$} & $\begin{array}{l}\text { TSSC } \\
\text { Mean } \pm \text { SD }\end{array}$ & \multicolumn{2}{|c|}{$\begin{array}{l}\text { NRS } \\
\text { Mean } \pm \text { SD }\end{array}$} & \multicolumn{2}{|c|}{$\begin{array}{l}\text { TS } \\
\text { Mean } \pm \text { SD }\end{array}$} & \multicolumn{2}{|c|}{$\begin{array}{l}\text { RS } \\
\text { Mean } \pm \text { SD }\end{array}$} \\
\hline & & 12.610 .02 & 11.35 & 0.01 & 15.22 & $0.01^{*}$ & 3.28 & 0.01 \\
\hline & Fanta & 12.140 .01 & 2.71 & 0.01 & 9.75 & 0.01 & 6.89 & 0.01 \\
\hline & Coke & $10.460 .01^{*}$ & 8.26 & 0.01 & 14.35 & $0.01^{\wedge}$ & 5.64 & 0.01 \\
\hline & 5 Alive & 12.850 .01 & 5.64 & 0.01 & 15.22 & $0.01^{*}$ & 9.28 & 0.01 \\
\hline \multirow[t]{3}{*}{ 7-up bottling company } & 7-up & $9.74 \quad 0.01$ & 43.25 & 0.01 & 55.97 & 0.02 & 20.45 & 0.01 \\
\hline & Pepsi & 8.28 & 19.47 & 0.02 & 36.65 & 0.02 & 16.16 & 0.01 \\
\hline & Mirinda & $11.90 \quad 0.02$ & 60.3 & 0.01 & 68.90 & 0.01 & 5.46 & 0.01 \\
\hline Classic beverage limited & La casara Apple drink & $9.98 \quad 0.01$ & 1.71 & 0.01 & 14.37 & $0.01^{\wedge}$ & 12.57 & 0.01 \\
\hline GlaxoSmithKline & Ribena & $11.90 \quad 0.01$ & 27.32 & 0.01 & 36.65 & 0.02 & 7.88 & 0.01 \\
\hline $\begin{array}{l}\text { Frutta juice and service } \\
\text { Nig Ltd }\end{array}$ & California sun & $12.61^{\wedge} 0.01$ & 1.43 & 0.01 & 13.74 & 0.02 & 12.24 & 0.01 \\
\hline \multirow{2}{*}{$\begin{array}{l}\text { Bobo food and beverage } \\
\text { Ltd }\end{array}$} & Bobo strawberry milk drink & 0.01 & 65.45 & 0.01 & 68.90 & 0.01 & - & - \\
\hline & Bobo orange & 7.06 & 14.85 & 0.02 & 29.76 & 0.02 & 14.14 & 0.01 \\
\hline Condia Nutrition & Twist Apple fruit milk drink & 13.310 .01 & 8.21 & 0.01 & 15.70 & 0.01 & 7.06 & 0.01 \\
\hline \multirow[t]{4}{*}{ Chi-Limited } & Capri-sonne orange drink & $12.61^{\wedge} 0.01$ & 8.19 & 0.01 & 11.36 & 0.02 & 2.76 & 0.01 \\
\hline & Chivita (apple juice) & 11.420 .01 & - & & - & & - & \\
\hline & Chivita (orange) & $10.46^{*} 0.02$ & 7.68 & 0.01 & 17.25 & 0.01 & 9.28 & 0.01 \\
\hline & Hollandia yoghurt & 16.320 .01 & 64.77 & 0.02 & 68.20 & 0.02 & - & \\
\hline
\end{tabular}
RS: Statistical significant differences $(p<0.0001)$ were recorded in all the samples for $R S$

TS: Statistical significant differences $(p<0.0001)$ were recorded in all except those with the same symbols TSSC: Statistical significant differences $(p<0.0001)$ were recorded in all except those with same symbols There were variations in physical and chemical parameters evaluated in these beverages 
agent is very significant $[5,16,20]$. A single acidic attack is inconsequential but if repeated, the power of saliva to handle the acid attack may be overwhelmed. If the challenge is regular and there are few or no protective factors, this may be hostile as in caries susceptible people [7].

Brix is another evaluated parameter which is a measure of dissolved solids (proteins, lipids, mineral salts, vitamins, glucides, organic acids, pigments and other substances. It has a correlation with the stickiness of the ingested foods which facilitates its retentions on the dental surfaces [8]. In our study, the TSSC (Brix values) ranged from 6.81 for Bobo straw berry to 16.32 for Hollandia yoghurt. The fruit juices in our study seemed to have high Brix 10.46 for chivita orange to 13.31 for Twist Apple fruit drink. This is in consonance with the work done in Brazil [8]. Sugar content of these beverages showed variation. These include, reducing sugar, Nonreducing sugars and total sugars. The total sugar ranged from 9.75 for Fanta to 68.90 for Bobo straw berry and Mirinda respectively. Chivita (Apple juice) recorded no total sugar. Worthy to note is the high values of these beverages. The values are higher than the ones reported by other researchers $[8,21,22]$. Frequent consumption of these drinks combined with poor oral hygiene may lead to caries. Reducing (glucose) and non-reducing sugars (Sucrose) can be metabolized by $S$. mutans. Notwithstanding, these microorganisms have greater capacity of forming glucans from sucrose. This sugar is a substrate for glucosyl transferase (GTF) which can be of three types GTF-B, GTF-C and GTF-D. The glucans mediate the adherence of microbial cells to dental surface, favoring bio film formation $[8,23]$.

\section{CONCLUSION}

The beverages assayed in this study had low $\mathrm{pH}$ and elevated total sugar content except chivita apple and so differ in their erosive and cariogenic potentials. Regular consumption of these drinks whether soft drinks or fruit juices should be discouraged. Parents and care givers should be educated on the consequences of these beverages on dental hard tissues when consumed regularly especially by children. Healthy dietary habit and proper oral hygiene produce should be encouraged. Oral education should be incorporated into school curriculum. Habits that aid remineralization should be encouraged.

\section{DISCLAIMER}

The products used for this research are commonly and predominantly use products in our area of research and country. There is absolutely no conflict of interest between the authors and producers of the products because we do not intend to use these products as an avenue for any litigation but for the advancement of knowledge. Also, the research was not funded by the producing company rather it was funded by personal efforts of the authors.

\section{ACKNOWLEDGEMENT}

Authors wish to appreciate the heads and staff of Departments of Microbiology and Clinical Chemistry of University of Nigeria Teaching Hospital, Ituku Ozalla, Enugu for availing us the use of their laboratories to carry out this work. The authors say thank you for your cooperation. The authors funded the research.

\section{COMPETING INTERESTS}

Authors have declared that no competing interests exist.

\section{REFERENCES}

1. Touger - Decker $\mathrm{R}$, Van Loveren $\mathrm{C}$. Sugars and dental caries AM J CLIN Nutr. 2003;78(4):881S-892S.

Available:https://doi.org/10.1080/ode.61.1. 25.28

2. Mishra MB, Mishra S. Sugar sweetened beverages: General and oral health hazards in children and adolescents. Int $\mathrm{J}$ Clin Pediatr Dent. 2010;4(2):119.

Available:https://www.ncbi.nin.n.h.gov.>arti cle

(Accessed 29/02/20)

3. Seow WK, Thong KM. Erosive effects of common beverages on extracted premolar teeth. Aust Dent J. 2005;50(3):173-178.

4. Arnadottir Inga $B$, Saemundsson SR, Holbrook WP. Dental erosion in Icelandic teenagers in relation to dietary and life style factors. Acta Odontol Scand. 2003; 61(1):25-28.

5. Bamise CT, Kolawol KA, Oloyede EO. The determinants and control of soft drinkincited dental erosion. Arch. Oral Res 2009;5(2):141-154.

6. Banan LK, Hegde AM. Plaque and salivary $\mathrm{pH}$ changes after consumption of fresh juices. The Journal of Clin Ped Dent 2005; 30(1):9-13. 
Available:https://doi.org/10.17796/jcpd.30. $1.40145263 j 4506793$

7. Goel 1, Navit S, Mayall S, Rallan M, Navit $P$, Chandra S. Effects of carbonated drink and fruit juice on salivary $\mathrm{pH}$ of children: An in vivo study. International Journal of Scientific Study. 2013;01(03):60-69.

Available:https://doi.org/10.17796/jcpd.30. $1.40145263 j 4506793$

8. de Almeida LD, Abilio G, Cavalcante MT, Castro RD, Cavalcanti AL. Cariogenic and erosive potential of industrialized fruit juice available in Brazil. Braz J Oral Sci. 2017; 9(3):351-357.

9. Khan F, Young WG, Law V, Priest J, Daley TJ. Cupped lesions of early onset dental erosion in young south east Queensland adults: Aust. Dent J. 2001;46:100-107.

Available:https://doi.org/10.1111/j.18347819.2001.tb00564.x

10. Daily Trust Nigeria; 2017.

11. Wojeicki JM, Heyman MB. Malnutrition and the role of the soft drink industry in inproving child health in sub-Saharan Africa Pediatrics. 2010;126(6):e1617e1621.

Available:https://doi.org/10.1542/peds.201 0-0461

12. Marya CM, Satija G, Nagpal R, Kapoor R, Ahmad A. In vitro inhibitory effect of clove essential oil and its two active principles on tooth decalcification by apple juice. International Journal of Dentistry; 2012. Available:https://doi.org/10.1155/2012/759 6

13. Cavalcanti AL, Oliveira OS, Evangelista APDA, Vieira FF, Granville - Garcia AF, Cavalcanti $\mathrm{CL}$. $\mathrm{pH}$ and total soluble solid content in concentrated and diluted in natural tropical fruit juice. Acta Stomatol Croat. 2008;42(3):229-234.

14. Cairns AM, Watson M, Creanor SL, Foye $\mathrm{RH}$. The $\mathrm{pH}$ and titratable acidity of a range of diluting drinks and their potential effects on dental erosion. J. Dent. 2002;30(7-8):313-317

Available:https://doi.org/10.1016/S03005712(02)00044-1
15. Aswini YB, Tangade PS, Ankola AV, Nagesh L, Pradnya, $H$. The effect of different methods of drinking a carbonated beverage on the $\mathrm{pH}$ of dental plaque: An in vivo study: Oral health Prev. Dent 2005;3 (4):237-241.

16. Association of Official Analytical Chemists. Official methods of analysis $17^{\text {th }}$ ed. Arlington; 2000.

17. Lussi A, Jaeggi T. Chemical factors. Monogr Oral Sci. 2006;20:77-87.

Available:https://doi.org/10.1159/00009335 3

18. Davani R, Walker J, Quian F, Wefel JS. Measurement of viscosity, $\mathrm{pH}$ and titratable acidity of sport drinks. J. Dent. Res. 2003; 82(Special issue A).

19. West NX, Hughes, JA, Addy M. Erosion of dentin and enamel in vitro by dietary acids: the effect of temperature, acid character, concentration, and exposure time. J Oral Rehabil. 2000;27(10):875-80.

Available:https://doi.org/10.1046/j.13652842.2000.0058.x

20. Zero DT. Etiology of dental erosion extrinsic factors. Eur. J Oral Sci. 1996; 104(2pt2):162-177.

Available:https://doi.org/10.1111/j.16000722.1996.tb00065.x

21. Pinheiro AM, Fernandes, AG, Fai AEC, Prado GM, Sousa PHM, Mais GA. Chemical, physiochemical and microbiological evaluation of single strength fruit juices; pineapple, cashew, apple and passion, Cienc Tecnol Aliment. 2006;26:98-103

Available:https://doi.org/10.1590/S010120612006000100017

22. Chaves MCV, Gouveia, JPG, Almeida FAC, Leite JCA, Silva FH. Physicohemcial characterization of the acerola juice. Rev Biol Cienc Terra. 2004;4:1-10.

23. Borges MF, Castilho, ARF, Pereira CV. Influence of sucrose, lactose and glucose + fructose on the cariogenic potential of S. mutans: An in situ and in vitro study. Rev. Odonto Ciencia. 2008;23: 360-364.

(c) 2020 Uzoamaka et al.; This is an Open Access article distributed under the terms of the Creative Commons Attribution License (http://creativecommons.org/licenses/by/4.0), which permits unrestricted use, distribution, and reproduction in any medium, provided the original work is properly cited.

Peer-review history:

The peer review history for this paper can be accessed here: http://www.sdiarticle4.com/review-history/55738 